EESTI NSV TEADUSTE AKADEEMIA TOIMETISED 1953. II k, nr. 2

ИЗВЕСТИЯ АКАДЕМИИ НАУК ЭСТОНСКОИ ССР 1953. Том II. ^ 2

\title{
TALLINNA TEKKIMISEST JA VANUSEST
}

\author{
H. MOORA.
}

ajalooteaduste doktor

Nōukogude Baltimaade linnade ajalugu on alles mitteküllaldaselt uuritud. Olgugi et ei vōi olla kahtlust, et linnad tekkisid siin, nagu kōikjal mujalgi, kohalike rahvaste sisemise arenemise tagajärjel, teatud arenemisastmel, kus tootlike joudude kasv ja ühiskond saavutasid vastava taseme, ei ole meil nende protsesside konkreetseks jälgimiseks veel. küllaldaselt faktilist materjali. Seda asjaolu ongi kasutanud baltisaksa ajaloolased ja nende sabas sörkivad kodanlik-natsionalistlikud eesti ajaloolased selleks, et tōsiasju sihilikult moonutades kujutada linnade tekkimist Baltimaadel, sealhulgas ka Eestis, saksa-skandinaavia feodaalide "ajaloolise teenena”, kui „heategu" siinseile „mittekultuurseile” rahvaile.

Viimastel aastatel, seoses Lääne imperialistide poolt uue sôja ettevalmistamiseks tehtava propaganda tugevnemisega, on nende teenistuses seisvad ,ajaloolased" jälle hakanud üles soojendama vanu fantastilisi ,teooriaid” Baltimaade linnade rajamisest läänepoolsete sissetungijate poolt, püüdes nõnda „ơigustada” agressiooni meie maa vastu. Eesti linnade ajaloo uurimine, uute materjalide muretsemine nende tekkimise kohta, et sellega kummutada Lääne agressorite teenistuses olevate ",ajaloolaste" väljamõeldisi, on seega mitte ainult suure teadusliku väärtusega, vaid ühtlasi ka olulise poliitilise tähtsusega ülesanne.

Tuleb märkida, et uue arheoloogilise ainese kogumine ja vanade kirjutatud allikate, samuti ka keeleliste andmete, nende seas kohanimede uurimine ja muude materjalide uus läbitöötamine on viimastel aastakümnetel sundinud kodanlikke uurijaidki möönma, et Baltimail olid juba enne saksa-skandinaavia feodaalide sissetungi XIII sajandi algul olemas teatud linnataolised keskused. Järjest kasvav faktide hulk on üha veenvamalt näidanud, et Baltimaade linnad olid alguse saanud X-XII sajandil kohaliku käsitöö arenemise ja sisekaubanduse kasvu tagajärjel ja et ühtlasi läbikäimise tihenemine naabruses olevate, märksa varem tekkinud Vene linnadega (Novgorod, Pskov, Polotsk jt.) avaldas sellele suurt mõju. Niisugusele tulemusele Tallinna tekkimise kohta jōudis isegi kodanlik ajalookirjutaja A. Süvalep ! Säärane seisukoht, iseäranis Venemaaga kaubandusliku läbikäimise tähtsuse rōhutamine ei võinud aga muidugi sobida valitsevale kodanlik-natsionalistlikule kildkonnale. Et seda ei saadud ümber lükata, püüti seda kas „unustada" vổi leiutada selle asemele uusi „seletusi". Oheks niisuguseks „,seletuskatseks” ongi P. Johanseni uus, 1951. a. ilmunud ,uurimus" Tallinna

I A. S ũ va lep, Muinas-Tallinn ja eestlaste väliskaubandus, Vana Tallinn III. Tallinn, 1938, Ik. $48 \mathrm{jj}$. 
tekkimise küsimuse kohta \%. P. Johansen, kes varem oli ideeliseks teerajajaks hitlerlusele, on pärast selle kokkuvarisemist asunud teenima Lääne imperialiste. Temagi ei saa eitada asula olemasolu Tallinna kohal enne saksa-taani feodaalide sissetungi. Hoolimata sellest, et ta on sunnitud möönma, et selle nimetus, Kolõvan, mis esineb nii araabia geograaf Idrisil kui ka vana-vene kroonikais, on ilmselt eesti päritoluga, püüab ta lapsikult tōestada, et asula olevat rajanud mitte eestlased, vaid ojamaa rootsi , asunikud". On iseloomulik, et Johansen püüab oma väite tõestamisel teadaolevaid fakte mitut viisi ,tõlgendada", nende otsesest mōttest kōrvale puigelda, omistades aga seejuures suure tähtsuse hoopis kahtlase väärtusega rahvaluulelistele materjalidele.

Missugused on need faktid, mis meil on teada Tallinna köige varasema olemasolu kohta?

Alustame kirjalike allikatega. Siin seisavad esikohal juba mainitud araabia geograaf Abu-Abd-Allah-Mohammed Idrisi andmed. Idrisi (1099-1166) oli araabia päritoluga õpctlane, kes kuulus Sitsiilia normanni kuninga Roger II õukonda. Uhelt poolt rohke varasema kirjanduse urimise alusel, teiselt poolt aga ka oma paljudel isiklikel reisidel kogutud või teistelt kaasaegsetelt reisijatelt saadud andmete pōhjal koostas ta kuningale 15-aastase töö tulemusena tol ajal tuntud maailma kaardi koos selle juurde kuuluva seletava tekstiga. See suur töö valmis 1154 . a. jaanuaris ${ }^{3}$. Idrisi kaart koosneb 70 lehest ja jagab maailma pöhjast lõunasse seitsmeks vööndiks ehk , ,kliimaks" ja idast läände kümneks vööndiks ehk osaks. Seitsmenda „kliima” 4. osas, 64. lehel asetsevad Baltimaad (v. tahv. I). Oli loomulik, et nii suure ja erisugustest allikatest saadud materjali kokkuvõtmisel Idrisil juhtus eksifusi vōi arusaamatusi. Kõik uurijar on aga arvamisel, et pōhiliselt on ta teated õiged ja et neid tuleb pidada oma aja kohta tähtsaks allikaks 4 .

Balti mere ümbrust hõlmava kaardiosa kohta iitleb ta tekstis: .,Selles seitsmenda kliima neljandas osas paikneb suur osa maast ar-Rusi (Vene) ja maad Finmark (Soome), Tabast (Häme), Astland (Eesti) ning Madžus (?)". Edasi kirjutab ta: „Astlanda linnade hulka kuulub ka Koluvan (või Koluvani). See on väike, suure kindlustise taoline linn. Ta elanikud on maaharijad ja nende tulu on kasin, kuid neil on palju karja." On huvitav, et Idrisi edasi märgib ära vahemaa Koluvani ja Novgorodi (Hulmkara) vahel, millest i'mneb Koluvani otsene suhtlemine Novgorodiga. Idrisi andmed Koluvani kohta kōnelevad kindlasti konkreetsest linnusest ja selle elanikest. Et neile maaharimine Tallinna kehvapinnaselises ïmbruses suurt tulu ei toonud, on usutav samuti nagu seegi, et neile karjakasvatus seepärast elu ülalpidamiseks tähtsat lisa andis. Ei ole nii siis pōhjust nendes Idrisi teadetes kahelda.

Teiseks allikaks on Läti Henriku Liivimaa kroonika XXIII peatüki 2. osas toodud kirjeldus Taani kuninga Valdemar II väe sissetungist Tallinna aastal 1219: ,Sel ajal tōusis ka Taani kuningas suure väega, ja tulid temaga Lundi kiriku auväärne arkipiiskop Andreas ja piiskop Nikolaus ja kolmas piiskop, kuninga kantsler, samuti nendega eestlaste piiskop Teodorich, kes varemini oli pühitsetud Riias ja kes oli maha jätnud Liivimaa kiriku, et liituda kuningaga, ja slaavlaste vürst Wizzlaus omadega. Nad kõik läksid

2 P. Johansen, Nordische Mission, Revals Grūndung und die Schwedensiedlung in Estland. Stockholm 1951.

${ }_{3}$ Б. А. Р ыба ков, Русские земли по карте Идрнси 1154 года, Краткие сообще ния о докладах и полевых нсследованнях Инстнтута историн матернальной культуры AH CCCP, вып. XLIII, 1952, стр. 5 .

4 O. J. Tallgren-Tuulio, Idrisi. La Finlande et les autres pays baltiques orientaux. (Studia Orientalia III). Helsinki 1930. - O. J. T u u li o (T a ll g re n). Du nouveau sur Idrisi. Edition critique, traduction, études par -. (Studia Orientalia VI), Hel. sinki 1936. 


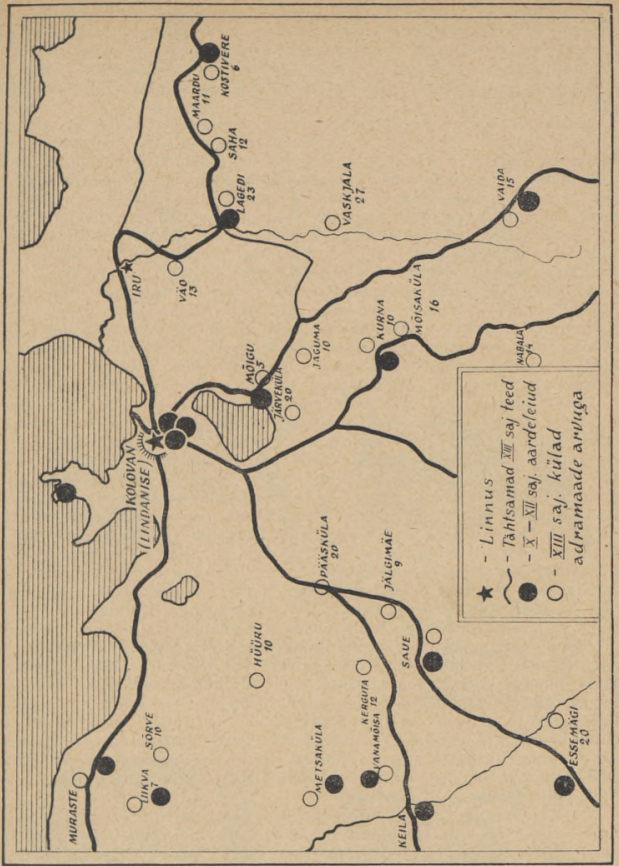

Joon. 1. Tallinn ja selle ümbrus $\mathrm{X}-\mathrm{XIII}$ sajandini.

maale sōjaväega rävalaste maakonnas ja asusid Lindanisesse, mis oli endine rävalaste kants. Ja, lōhkunud vana kantsi, hakkasid ehitama uut."

Rävala rahvale tuli maabumine üllatusena, sest alles pärast taanlaste maaletungi hakkavad nad koguma väge ja üritavad kolmandal päeval rünnaku vōöraste vallutajate vastu. Rünnak on alguses edukas, taanlased suudavad aga siiski endid koguda ja rävala väe tagasi lüüa. Seejärel jätkavad 
taanlased endise rävalaste kantsi kindlustamist, asudes siit järk-järgult alistama ümberkaudset maad. Mōne aja pärast on Tallinna linnus seevôrra kindlustatud, et kuningas enamiku väega vōib lahkuda, jättes kantsi vajaliku garnisoni ühes mitmete ilmlike ja vaimulike võimukandjatega. Ummarguselt kolm kuud pärast maabumist Tallinna all mainitakse Valdemari juba jälle oma kodumaal ${ }^{5}$.

Sellest kirjeldusest tuleneb kōigepealt, et kuni 1219. aastani oli nüüdsel Tallinna Toompeal eestlaste kants. Taanlased saavad selle oma vôimusesse vōitluseta. Viimasest asjaolust on P. Johansen püüdnud järeldada, et eestlaste linnus olevat olnud maha jäetud. Selline oletus ei vổi ometi ôige olla, sest niisuguse tähtsa keskuse linnus ei vôinud olla hüljatud. Oigem on arvata, et linnuses ei olnud taanlaste ïllatava maabumise silmapilgul küllałdaselt väge, et oleks olnud võimalik vastu panna. Seepärast pōgenes seal olnud rahvas metsadesse, nagu see säärastel puhkudel oli tavaline. Läti Henriku jutustusist teame, et muudki linnused Baltimail ainult siis vastu panid, kui neisse oli enne rünnakut suudetud koguda vajalikul arvul sõjaväge. Et linnus oli olemas, järeldub Läti Henriku ütlusest, et ta vanad kindlustised osalt maha kisti, enne kui taanlased asusid oma tavade ja oma sõjatehnika kohaseid uusi ehitama. Osa vanu kindlustisi jä: kindlasti püsima ja uued ehitised ei võinudki olla kuigi suured võrreldes nendega, sest juba lühikese aja pärast vōis, nagu nägime, kuningas peaväega siit lahkuda.

Teiseks on märgitud, et kroonika mainitud kohas ei kōnelda linnuse juures olnud asulast. Kuid ka eestlaste ja teiste Baltimaade rahvaste muude suurte linnuste, nagu Otepää, Tartu ja Viljandi vôi Jersika ja Mežotne juures ei maini Läti Henrik asulaid. Nende juures toimunud vôitluste kirjeldamisel kōneleb ta ikka ainult linnustest enidist ja neistki väga lühidalt, ega maini asulaid. Ja ometi on arheoloogilised kaevamised näidanud, et mitmete nende linnuste juures olid suured linnataolised asulad. Asula mittemainimine Läti Henriku poolt ei tähenda seega kaugeltki veel asula puudumist.

Ja isegi siis kui asula võis puududa, ei ütle see iseendast veel palju. Viimaste aastate uurimistööd on näidanud, et Baltimaade muistsed linnused ja linnataolised keskused polnud kōik oma laadilt ühtlased, vaid nende seas võib eraldada mitut erinevat tüüpi. Näib, et osal suurtest linnustest polnud asulat väljaspool kindlustuse valli. Nõnda ei ole näiteks asula jälgi avastatud väljaspool Varbola valli. Varbola oli teatavasti üks eestlaste suurimaid ja kõige võimsamaid linnuseid. Arheoloogilised uurimistööd Varbolas on avas. tanud linnuse avaralt, 2 ha suuruselt õelt kultuurkihi, milles on jälgi elamuist, rohkesti toidujäätmetena ära visatud loomaluid ja käsitöö, eriti metallitöötlemise jälgi. Seega on siin valliga piiratud ouel olnud asula, milles on tehtud käsitööd ja kus ilmselt elasid kaubitsejadki. Varbola oli suur keskus. mis oli tuntud kaugel väljaspool eestlaste maad - seda tunnevad hästi näit. vene kroonikad. Ja ometi koondus selle elu ainult valliga piiratud alale, $\mathrm{s}$. o. linnusesse enesesse.

Samasugune võis lugu olla ka muistse Kolôvani-Tallinnaga. Toompea kingul asetsenud linnuse pindala on avar, tunduvalt suurem kui Varbola oma, ja ta suutis seega mahutada suuremat asulat. Asula olemasolu linnuses näitasid ka kaevamised 1952. aastal, millest veel kõneldakse allpool. 1953. a. Tallinna vanalinnas teostatud arheoloogilise uurimise ülesandeks oligi küsimuse selgitamine, millal tekkis asula Kolōvani linnuse kōrvale.

Niihästi vanadest kirjalikest allikatest kui ka arheoloogilistest andmetest ilmneb, et Tallinna asupaika jooksid juba X-XI sajandil kokku suured liiklusteed. Tallinnast enesest ja ta lähimast ümbruskonnast on leitud rida

5 Seda ja Tallinnas mabumise aega ei teata Läti Henrik, vaid need selguvad teistest allikatest, vt. Ген н их Л а тв й ски й, Хровика Линонии. М.-Л. 1938. стр. 547, 548, прнмечания 271, 272 
suuremaid hōbeda-aardeid, mis sisaldavad sadu araabia ja lääne-euroopa X-XII sajandi münte (vt. joon. 1). Samasuguseid mündileide on teada. ka Eesti teiste muistsete keskuste, nagu Tartu, Viljandi, Toolse ja Pärnu ümbrusest. Need faktid on tōendiks X-XII sajandi Kolōvani-Tallinna tähtsusest eestlaste käsitöö ja sisekaubanduse keskusena ja ühtlasi sadamana, kust algas üks veeteedest, mis ühendas mitte ainult eestlaste maid, vaid ïhtlasi ka Venet Läänega.
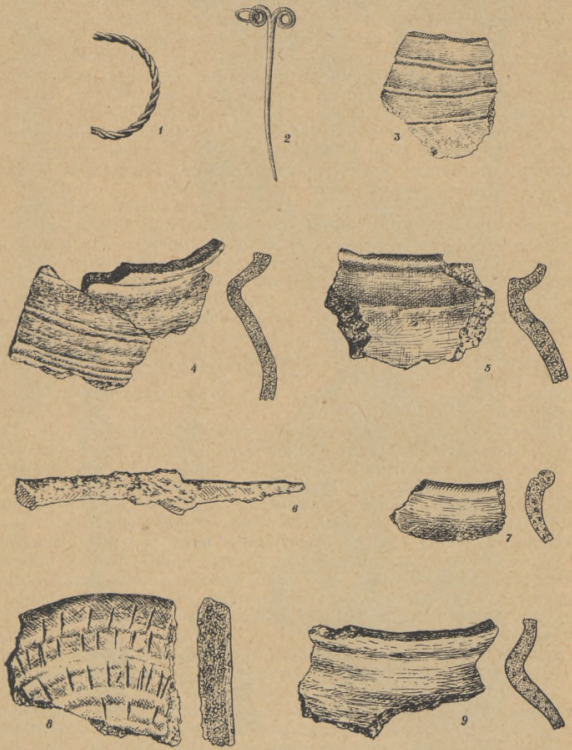

Joon. 2. Esemeid arheoloogilistelt kaevamistelt Tallinna Toompeal 1952. aastal: 1. Novgorodipărane punutud käevõru, pronksist (katki), 2. Eesti naise linikukinnitamise nōel, pronksist. $3-5,7,9$. Kedral valmistatud savinōude katkendid. 6 . Nuga (katki). 8. Savist pöletatud ketta katkend.

$I-5$ on kaevandist. Tervishoiuministeeriumi esiselt platsilt, ülejäänud kaevandist Toomkooli tänavalt. 
Kolōvani ja teiste mainitud keskuste tekkimist tuleb pidada kōnesoleva aja kohta täiesti seaduspäraseks nähtuseks. Me teame ju, et $\mathrm{X}$-XII sajandil elas muistne eesti ühiskond üle ajajärku, kus hakkasid kujunema feodaalsete suhete algmed ${ }^{6}$. Sellele ajale on omane algav käsitöö eraldumine pōllutööst ja käsitöö ning kaubanduse koondumine linnataolistesse asulatesse, millest üks silmapaistvamaid oli muistne Kolõvan.

Materjale on saadud ka arheoloogiliste urimiste tulemusena Tallinnas eneses. Teatavasti teostas Tallinna linnamuuseum 1952. a. sügisel esmakordselt arheoloogilisi kaevamisi Toompeal. Neid töid juhatas NSV Liidu Teaduste Akadeemia Materiaalse Kultuuri Ajaloo Instituudi vanem teaduslik töötaja ajalooteaduste kandidaat $\mathrm{S}$. A. T a $\mathrm{r}$ a k a nov a ${ }^{7}$, kes oli juhatanud eelmistel aastatel samasuguseid töid Pskovis. Kuigi 1952. a. kaevamised kui esmakordsed olid alles väga piiratud ulatusega, näitab saadud arheoloogiline materjal (arvukad savinônukillud, loomaluud ja tüüpilised eestipärased metallesemed, vt. joon. 2), et Toompeal oli eestlaste kindlustatud asula olemas kahtlematult juba XI-XII sajandil, mis kinnitab Idrisi andmeid. Paljastatud vana kultuurkihi osad on nii paksud, et nad ei jäta kahtlust, et see linnus polnud mingiks ajutiseks pelgupaigaks, vaid oli a l a tiselt as ustatud, nagu kuuleme Idrisiltki.

1953. a. võeti arheoloogilised kaevamised ette Tallinna vanalinnas raekoja platsil, ligemale 500-ruutmeetrilisel alal. Kaevamiste juhataja ajalooteaduste kandidaadi S. A. Tarakanova esialgses aruandes esitatud tõsiasjad võimaldavad juba teha mōningaid kokkuvôtteid tööde tulemustest.

Kōigepealt märgitakse S. A. Tarakanova aruandes suurt vahet eelmisel aastal Toompealt saadud leiumaterjali ja 1953. aastal raekoja platsilt saadud leidude vahel. Eelmises on palju rohkem välismaise päritoluga XIII-XIX saj. toredusesemeid, kuna järgmine on märksa lihtsam ja koosneb enamikus kohaliku päritoluga ainesest. Selles ilmneb kujukalt VanaTallinna sotsiaalne topograafia: Toompeal elas võõras feodaalne ladvik. all-linnas aga lihtne linnaelanikkond, kelle hulgas valdava enamiku moodustasid eestlased.

Jättes siin körvale hilisemate sajandite materjali, märgime, et S. A. Tarakanova ühendab teatavat sügavamat kaevandi horisonti läbivat süsist kihti Tallinnas 1288. a. aset leidnud suure tulikahjuga. Sellest veel sügavamal asuvaid kihte dateerib S. A. Tarakanova X-XIII sajandiga.

Neis kaevandi sügavamais osades leidus jäänuseid puuehitistest, mida S. A. Tarakanova peab väikesteks poodideks. Nende ümbert leiti rohkesti nahkjalatsite osi ning jalatsite valmistamisel maha langenud nahalöigendeid ja ribasid. Poodides järelikult mitte ainult müüdi, vaid ka valmistati ja parandati jalatseid. Suurel arvul leidus siin ka osi mitmesugustest puuvitsikutest ja õonestatud või treitud puunōudest - seega puitu töötlevast käsitööst. Leidude seas on ka kasetohust vakkade osi, nagu neid on leitud Eesti muistseist linnustest.

Uksikuist esemeist mainitagu tinast pitsatijäljendit (joon. 3, 7), mis pärineb arvatavasti XIII sajandist, elevandiluust varases gooti stiilis nikerdatud kujukest (joon. 3, 6), mis on arvatavasti pärit mônest kantavast altarikesest, jm. asju, mis ilmselt on saksa käsitöö tooted. Sügavamad kihid ja eriti kaevandi kirdenurgas avastatud raudkividest vooderdusega kaev andsid rea puhteestipäraseid pronksist hoburaudsōlgi XI-XIII sajandist.

Nagu vanade asulate kohal ikka, leiti siitki kõige arvukamalt savi-

6 Vt. Eesti NSV ajalugu. -Tallinn, 1952, lk. 24-26.

Vt. S. A. Tarakanova, Arheoloogiline kaevamine Tallinnas. ENSV TA Toinetised 1952. I k., nr. 4, Ik. 55 jj. 


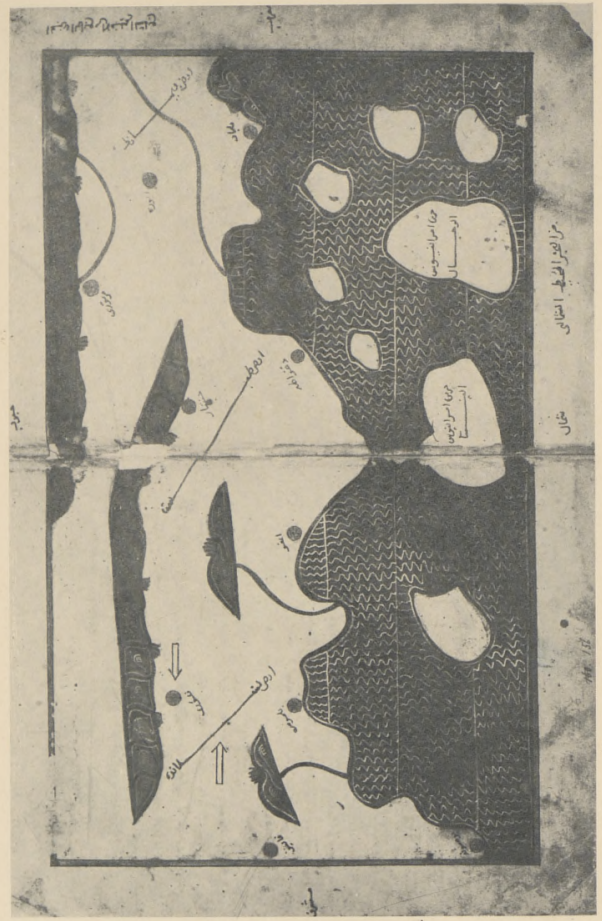

严

를

E.

츨

อ $\frac{19}{9}$

吾

플

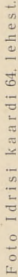



nōude kilde. Nende seas valitsevad samasugused kedral valmistatud savinōud, nagu neid esines Toompea sügavainıas kihis (vt. joon. 2) ja teistelt Eesti linnustelt saadud leidude seas XI - XIII sajandist. Keraamika seas leidus ka môni üksik käsitsi vormitud nôu kild (joon. $3,1 I$ ).

Kedrakeraamika on oma vormidelt, savi koostiselt ja pōletusviisilt, sanuti nagu muu samaaegne Eesti alalt leitud keraamikagi, kõige lähemalt seotud vana-vene keraamikaga. S. A. Tarakanova arvates vastab see $\mathrm{XI}-\mathrm{XII}$ sajandi, osalt aga isegi IX - X sajandi vene keraamikale.
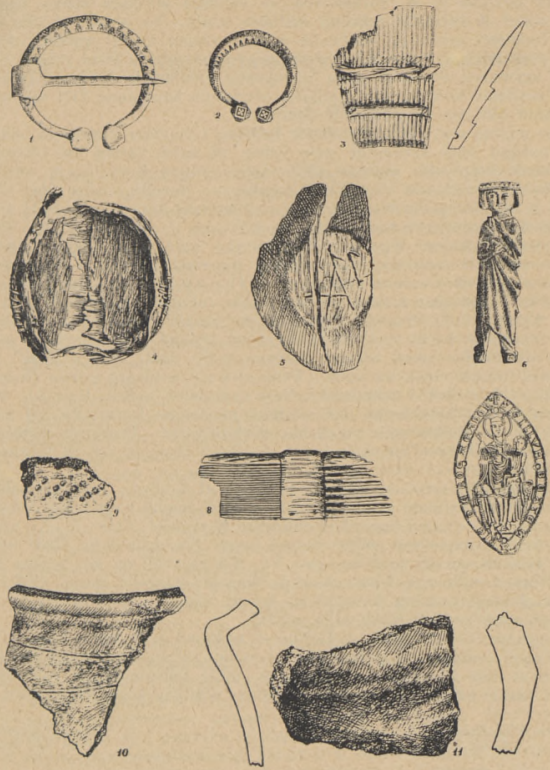

Joon. 3. Leide 1953. a. kaevamistelt Tallinna raekoja platsil. $I-2$. Eestipäraseid hoburaudsōlgi. 3. Puuvitsiku lauake vitste jäänustega. 4. Tohust vakakese pōhi. 5. Treituđ liuakese pōhi valmistaja peremărgiga, 6. Elevandiluust kujuke. 7. Pitsati jäljend, tinast. 8. Puust kamm. 9, 10. Kedral valmistatud savinōude kilde. II. Käsitsi valmistatud savinōu kild. 
Vähemal määral leidus kaevandi alumistes kihtides ka läänepoolset keraamikat, mis, nagu Tallinnast ja ta ümbruskonnast saadud X-XII sajandi mündidki, kõneleb Tallinna kokkupuuteist läänepoolsete naabritega. Kuid samuti nagu kaevamised Toompeal, ei andnud ka suur kaevand raekoja platsil mingit materjali, mis oleks tunnistanud Tallinna kohal oletatud rootsi asula olemasolust.

Kogu vanem leiuaines vastab materjalidele, mida on leitud X-XIII sajandi asulakohtadelt ja linnustelt mujal Eestis. Raekoja platsi kaevamistest järeldab S. A. Tarakanova, et Tallinna all-linna kohale hakkas juba alates X sajandist tekkima eestlaste asula. Ta arvab, et järelikult pidi Toompea asula ja kindlustis alguse saama veelgi varem. Kuigi sm. Tarakanova dateeringud peaksid mõnes osas olema pisut julged, tõestavad uurimised all-linnas nagu Toompealgi kahtlemata Kolôvani-Tallinna kohal eestlaste keskuse, eriti turukoha olemasolu kaua enne XIII saj. algul toimunud võõraste sissetungijate ilmumist.

Mis puutub veel mitmesugustesse Tallinna vanadesse nimedesse, siis on kōik uurijad ühel arvamisel selle kohta, et neist vanim on Idrisil ja vana-vene letopisides aastast 1223 alates esinev $\mathrm{Kol}$ òv a n, mis jäi vene keeles tarvitusele kuni XVIII sajandini. Samuti ollakse ühel arvamisel, et see nimi pärineb koha vanast eestikeelsest nimetusest. Seda nimetust on ühendatud eesti muinasvägilase Kaleviga - „Kalevanlinna”. Tegelikult polnud „kalev" algselt mitte isikunimi, vaid üldse ülikate nimetus, millest võib-olla saakski tuletada linna nimetust. Teine, Läti Henriku Liivimaa kroonikas esinev nimetus - Linda $\mathrm{n}$ ise on samuti vana ja ulatub ka tagasi aega enne taani feodaalsete vallutajate sissetungi XIII sajandi algul. Seda nimetust tarvitasid nähtavasti eriti skandinaavlased. Selle tähenduse kohta pole üksmeelt: ühed peavad seda germaani päritoluga nimetuseks, teised näevad ta tüves eesti sõna "lind", "litna", mis tähendas linnust, muistset linna. Vene allikais mōnikord esinev Леденец arvatakse tulenevat Lindanisest. Neljas nimetus saksa Reval, vene Ревель, pärineb kahtlemata muistse eesti makonna Rävala-Rävälä nimetusest; oli ju Tallinn selie maakonna peakeskuseks. Praeguse eestikeelse nimetuse .,T a ll i n n" päritolu kohta ei ole kahtlust, et see on lühenenud .Taanilinn".

Siin lühidalt esitatud tôsiasjad näitavad, et Kolōvan kui sadamakoht. liiklussōlm, kaubanduse ja käsitöö keskus tekkis samuti nagu teisedki muistsed eestlaste keskused kohaliku arenemise tagajärjel alates $\mathrm{X}-\mathrm{XI}$ sajandist. Selle kujunemisele mõjus ilmselt kaasa tihe suhtlemine Vene linnadega, eriti Novgorodi ja Pskoviga. XI-XII sajandil on see keskus juba laialt tuntud mitte ainult oma maal ja lähemate naabrite juures, vaid seda tunnevad isegi araabia kaupmehed, kellelt saadud andmete järgi mainib teda esmakordselt Idrisi 1154. aastal.

Seega on täiesti kindel, et Tallinn ei tekkinud alles saksa-taani vallutajate poolt asutamise tulemusena, vaid vallutajad maandusid siin just seepärast, et siin oli olemas vana keskus, mille höivamine oli vallutajaile seotud suurte kasudega, sest see võimaldas alistada kogu Pôhja-Eesti. 
EESTI NSV TEADUSTE AKADEEMIA TOIMETISED I953. II k., nr. 2 ИЗВЕСТИЯ АКАДЕМИИ НАУК ЭСТОНСКОИ ССР 1953. Том II, А 2

\title{
О ВОЗНИКНОВЕНИИ ГОРОДА ТАЛЛИНА
}

\author{
Х. А. MOOPA, \\ доктор исторнческих наук
}

История городов Советской Прибалтики еще недостаточно изучена. Хотя и не может быть никаких сомнений, что гюрода возникали здесь, как и везде, в результате развития местного общества, когда рост пронзводительных сил, а также само общество достигали определенного уровня развития, мы все же еще не располагаем в достаточной мере фактическими материалами для подробного прослеживания этих пропессов. Прибалтийско-немецкие, а также шедшне по их следам эстонские буржуазные нсторики использовали -это обстоятельство, чтобы, преднамеренно извращая факты, представить возникновение городов в Прибалтике как «историческую заслугу», как жблагодеяние» немецко-скандинавских феодалов по отношению к местным «некультурным» народам.

В последние годы, в связи с усилением пропаганды западных империалистов, налравленной на разжиганне новой войны, буржуазные «историки», стоящие на службе у них, вновь начали подогревать старые фантастические втеории» об основании прибалтийских городов западными захватчиками, стремясь таким образом «оправдать» направленную против нашей страны агрессию. Ввиду этого изучение истории городов Эстонии, собирание, изучение и обобщение новых материалов с целью выяснения подлинной их историн является задачей не только огромной научной, но и большой политической важности.

Следует отметить, что накопленные за последние десятилетия новые археологические материалы, изучение древних пнсьменных источников и языковых данных, в том числе топоннмики, а также других материалов, заставили даже отдельных буржуазных исследователей признать, что в Прибалтнке еще до немецко-скандннавской агрессии в начале XIII века имелись центры городского типа. Вся совокупность фактов убедительно свидетельствует о том, что возникновение городов Прнбалтики связано с развитием местного ремесленного производства и внутренней торговли в X-XII веках. Усиленне связей с соседними, возникшими значительно раньше русскими городами (Новгород, Псков, Полоцк и др.) оказало сильное воздействие на процесс их развития. В отношении возникновения Таллина к таким выводам пришел, например, даже эстонский буржуазный исторнограф А. Сювалеп ${ }^{1}$. Это толкование, в особенности же подчеркивание значения торговых отношений с Русью,

I A. S ü va le p, Muinas-Tallinn ja eestlaste väliskaubandus. Vana Tallinn III, Tallinn, 1938, Ik. 48 jj 
разумеется, было не по вкусу хозяйничавшей в Эстонни буржуазно-националистической клике. Поскольку это положение не удалось опровергнуть фактами, то о нем постарались «забыть», стремясь найти вместо него другие єобъясненияљ. Одной из таких попыток является новое, появившееся в 1951 году за граннцей жисследование» П. Иогансена 2.

П. Иогансен - в прошлом усердный прислужник гитлеризма, после его разгрома перешедший на службу к западным империалистам, - не в состоянии опровергнуть факта существования населенного центра в нынешнем Таллине еще до-вторжения немецко-датских феодалов.

Несмотря на то, что Иогансен вынужден признать явно эстонское происхождение древнего названия Таллина — «Колывань», встречающегося как у арабского географа Идриси, так и в древнерусских летописях, он все же упорно пытается «доказать», что этот населенный центр был основан не эстонцами, а шведскими поселенцами. Характерно то обстоятельство, что при доказательстве свонх положений Ногансен стремится по-своему «истолковать» уже известные факты, уклониться от них, придавая в то же время большое значение фольклорным материалам сомнительной ценности.

Каковы же те факты, которые нам известны о существовании древнейшего Таллина?

Начнем с письменных источников. Первое место среди них занимают сведения арабского географа Абу-Абд-Аллах Мохаммед Идриси (10991166), упомянутого выше. Идриси был придворным нормандского короля Рожера II, владевшего Сицилией. На основе изучения письменных источников, а также по им самим же собранным многочисленным данным нли по сообщениям современных ему путешественников Идрисн, в результате 15-летней усердной работы, составил для сишилийского короля карту известного тогда мира и снабдил ее сопроводительным текстом. Этот большой труд был завершен в январе 1154 пода ${ }^{3}$. Карта Идриси состоит из 70 листов, разделена на семь широтных зон - «климатов» и на десять меридиональных членений или частей. На 64-м листе, в 4-й части седьмого хклимата» находится Прибалтика (табл. I). Вполне естественно, конечно, что в столь большой труд, базировавшийся на материалах из самых различных источников, неизбежно вкрались некоторые ошибки и неточности. Но все ученые единодушно придерживаются того мнения, что в основном сведения его верны, и что труд его является важным для своего времени источннком !.

Об упомянутой части карты Идриси пишет: «В четвертой части седьмого климата-заключается большая часть страны ар-Руссий и страны Финмарк, страны Табаст, страна Астланда и страна Маджус». Далее Идрисн пишет: «К городам Астланды относится также город Колуван. Это маленький город вроде большой крепости. Жители его землепашцы и их доход скуден, но у них много скота». Любопытно, что Идрисн далее отмечает расстояние от Қолувани до Новгорода (Хулмкара), из чего вытекает факт наличия непосредственных связей Колывани и Новгорода. Сведения Идриси о Колывани определенно относятся к конкретному го-

2 P. Joha nsen, Nordische Mission, Revals Gründung und die Schwedensiedlung in Estland. Stockholm 1951.

з Б. А. Рыбаков, Русские земли по карте Идриси 1154 года. Краткне сообщения о докладах н полевых исследованиях Института историн матернальной культуры АН CCCP, вып. XLIII, 1952, стр. 5.

4. J. Tallgren-Tuulio, Idrisi. La Finlande et les autres pays baltiques orientaux. (Studia Orientalia III), Helsinki 1930. - O. J. Tu ul io (T a llg re n), Du nouveau sur Idrisi. Edition critique, traduction, études par-. (Studia Orientalia VI). Helsinki 1936 
родищу и к его жителям. Что земледелие на скудной почве окрестностей Таллина не могло давать его жителям больших доходов, это так же достоверно, как и тот факт, что скотоводство играло в жизни населения важную роль. Нет оснований поэтому сомневаться в достоверности сообщений Идриси.

Вторым источником является «Хроника Ливонни» Генриха Латышского. Описывая во второй части 23-й главы вторжение войск датского короля Вальдемара ПІ в северную Эстонию (1219 г.), автюр хроники говорит: «Поднялся в то время и король датскнй с большим войском, н пришли с ним достопочтенный архиепископ лундской церкви Андрей, епископ Николай и третий епископ, королевский канщлер, а также эстонский епископ Теодорих, ранее посвященный в Риге и оставивший ливонскую церковь, чтобы примкнуть к королю, и, наконец, Виццлав (Wizzlaus), князь славов, со своими. Все они высадились с войском в ревельской области, остановились в Линданисе, прежнем замке ревельцев, н, разрушив старый замок, стали строить другой, новыйх.

Высадка датских войск застала население Рявала врасплох, так как лишь после их высадкн собирается рявалаское ополчение, которое на третий день после высадки пытается дать отпор агрессорам. Атака эстонцев вначале имела успех, однако датчане успели оправиться и отразнть рявалаское войско. Ӓгрессоры продолжали укреплять захваченную эстонскую крепость и опираясь на нее, постепенно покоряли окружающие земли. Через некоторое время Таллинское городище уже настолько окрепло, что король с большей частью своих войск мог удалиться, оставив на месте лишь необходимый гарнизон и представителей духовной н светской власти. Примерно через три месяца после высадки пол Таллином Вальдемар был уже у себя дома ${ }^{5}$.

Из приведенного описания вытекает прежде всего то, что до 1219 года на месте нынешнего Тоомпеа (Вышгород) в Таллине находилось эстонское городнще, которым датчане вначале овладели без боя. Это обстоятельство послужило П. Иогансену ждоказательством» того, что городище было эстонцами уже покинуто. Однако этот вывод не может быть признан верным: пренебрежение столь важным центром неправдоподобно. Скорее всего, в городище в момент нападения на него не было достаточного для оказания сопротивления датчанам количества войск. Поэтому местное население, как это обыкновенно бывало в подобных случаях, разбежалось по лесам. Генрих Латышский сообщает, что и другие прибалтийские городища оказывали сопротивление врагам лишь в тех случаях, когда удавалось собрать достаточное количество военных сил. Факт же наличия городища подтверждается высказыванием Генриха Латышского о том, что прежнее укрепленное городище было частично разрушено, прежде чем датчане стали возводить новые, соответствуюшие их военной технике укрепления. Безусловно, часть старых укреплений сохранилась, а вновь воздвигнутые укрепления не могли быть большими, так как вскоре король Вальдемар, как мы выне указалн, с большей частью своих войск мог удалиться.

Правда, в упомянутой хронике ничего не сказано о наличии поселения возле городища. Однако и при других крупных городищах Прибалтики (Отепяа, Тарту, Вильянди, Ерсика, Межотне и др.) Генрнх Латышский не упоминает. поселений. Описывая происходившие у городищ сражения, он упоминает только о самих городищах и то лишь весьма

5 Этот факт, также как и дата высадки под Таллином, Генрнхом Латышским не приводится, сказанное явствует нз другнх нсточников. См. Генрнх Латвия̆скнй, Хроника Ливонии, М.-Л., 1938, стр. 547, 548, дримечания 271, 272. 
лаконично, не поворя о поселениях. На деле же, как показывают археологические раскопки, ко многим из этих городищ примыкали поселения городского типа. Факт умалчивания Генрихом Латышским поселений сам по себе далеко еще не отрицает существования таких поселений

Даже в том случае, если поселение у Таллинского городища действительно отсутствовало, и это еще ничего не доказывает. Исследования последних лет показывают, что древнне городища, а также городского типа центры в Прибалтике отнюдь не были одинаковыми: среди них встречаются различные типы. Повидимому, часть наиболее крупных городищ не имела поселений за укрепленным валом. Так, например, за укреплениями городнща Варбола не обнаружено никаких следов наличия древнего поселения. Как известно, Варбола одно из наиболее крупных и мощных городищ, древних รстонцев. На обширной площади (2 га) городища археологическими раскопками выявлен культурный слой, содержаший в себе остатки жилищ, множество костей животных, а также следы ремесленного пронзводства - остатки обрабатывавшихся деревянных и металлических изделий. Таким образом, здесь на огражденном валом дворе находнлось поселение, здесь люди занимались ремеслом, проживали также купцы. Варбола являлась крупным центром, хорошо известным далеко за пределами эстонских земель - o нем были хорошо осведомлены, например, русские летописцы. И все же вся многообразная жизнь этого. центра была сосредоточена внутри города-крепости, на площади, обнесенной укреплениями.

Так мотло обстоять дело и в древнем Таллине-Қолывани. Укрепление, находившееся когда-то на Тоомпеа, было просторным, значительно болльшим, чем Варбола, и могло, таким образом, вместить и большое поселение. Наличие последнего в самом укреплении засвидетельствовано также раскопками, о чем речь будет ниже.

Древние письменные памятники, как и археологические данные, говорят о том, что еще в X-XI веках к месту расположения Таллина стекались важные пути сообщения. В самом Таллине и в его блнжайших окрестностях найден целый ряд кладов серебряных монет, в том чнсле арабских и западноевропейских монет X-XII вв. (см. рис. 1). Аналогичные находки многочисленных монет известны и в окрестностях других древнейших эстонских центров (Тарту, Вильянди, Тоолсе, Пярну). Эти факты свндегельствуют о том, что Таллин-Колывань в X-XIII веках был важным ремесленным и торговым центром, а также гаванью, откуда начинался один из путей, соединявших не только эстонские земли, но и Русь с Западом.

Возникновение Колывани, а также других названных центров является вполне закономерным явлением той эпохи. В X-XII веках древнее эстонское общество переживало период зарождения феодальных отношений ${ }^{6}$. Этот период характеризуется процессом отделения ремесла от сельского хозяйства, началом концентращии торговли и ремесла в поселениях городского типа.

Археолюгическое изучение Таллина подтверждает сказанное. Қак известно, осенью 1952 гола в Таллине на Тоомпеа впервые пронзводились археологические раскопки ${ }^{7}$. Хотя раскопки 1952 года носнли разведывательный характер и велись в относительно ограниченных масштабах, - все же обнаруженный археологический материал (многочисленные черепки глиняных сосудов, кости животных, металлические изделия

- Иетория Әстонской ССР, Таллин, 1952, стр, 25-29.

7 C. А. Т ар аканова. Археологические раскопки в Таллине, Известия АН ЭСCP, N 4, 1952, стр. 58. 
эстонского происхождения, см. рис. 2) показывает, что на Тоомпеа существовало не позднее XI-XII вв. укрепленное поселение эстонцев, что подтверждает сведения Идриси. Мощность культурного слоя здесь столь значительна, что не может быть никаких сомнений в том, что городище это было постоянно заселено, как и сообщает Идриси.

В 1953 году были произведены археологические раскопки в нижнем городе, на Ратушной плошади. Была вскрыта плошадь размером около $500 \mathrm{M}^{2}$. В предварительном отнете руководителя работ кандидата исторических наук С. А. Таракановой отмечается резкое отличие материалов, добытых раскопками предшествующего года на Вышгороде, от материалов из раскопа текущего года в нижнем городе. Первые содержали значительно больше разного рода привозных предметов роскоши, находки же 1953 года имеют более простой характер и состоят в большинстве из местных изделий. Это наглядно показывает сощиальную топографию старого Таллина: на Вышгороде сидели верхи чужеземной знати, в нижнем же городе обитала масса городского населения, подавляющее большннство которого составляли эстонщы.

Не рассматривая более поздние материалы, отметим, что С. А. Тараканова связывает черный углистый слой, образующий в раскопе известный горизонт, с пожаром 1288 года. Подстилающие этот углистый слой наслоения она относит к X-XIII вв.

В этих нижних слоях обнаружены следы деревянных построек, которые С. А. Тараканова считает остатками ларьков. Среди этих остатков найдены сохранившиеся части кожаной обуви и большое количество обрезков кожи. В этнх ларьках, следовательно, не только продавалась, но и изготовлялась и чинилась обувь. В болышом количестве обнаружена также деревянная посуда, как точеная, так и изготовленная из дощечек. Среди находок имеются также остатки берестяной посуды, вполне сходной с посудой, обнаруженной на эстонских городнщах.

Из отдельных наиболее интересных находок назовем свинцовый оттиск печати XIII в., фигурку человека (рис. $3,7,6$ ), изготовленную из слоновой кости в раннеготическом стиле, входившую в свое время, повидимому, в переносный алтарь, и др. предметы, представляющие, очевндно, немецкое ремесленное производство. В самых нижних слоях и в особенности в обнаруженном в северо-восточном углу раскопа колодще, выложенном крупными валунами, найден ряд бронзовых подкововндных пряжек чнсто эстонского облика, датируемых XI-XIII вв. (рис. 3, 1, 2).

Как обычно на древних поселениях, на раскопанной площади обнаружено значительное количество керамики. Керамика представлена почти всецело сосудами, изготовленными на гончарном кругу, сходными с сосудами из нижних горизонтов вышгородских раскопов (рис. 2) и с керамикой эстонских городищ ХI-XIII вв. Помимо гончарной керамикн обнаружены также отдельные фрагменты лепных сосудов (табл. II, 11 ).

Круговая керамика совершенно сходна, как вообще современная ей эстонская керамика, по форме сосудов, составу теста и по обжигу с древнерусской керамикой. С. А. Тараканова датнрует древнейшую керамику нз таллинских раскопок XI-XII вв., отчасти даже X веком.

В небольшом количестве в нижних слоях обнаружены также черепки глиняных сосудов западнопо происхождения. Они попали сюда, как и западноевропейские монеты X-XII вВ., в результате обшения древних эстонцев с западными соседями. В раскопе на Ратушной площади, как и в раскопках на Вышгороде, не было обнаружено ни материалов скандинавского происхождения, ни следов шведского поселения.

Весь древнейший инвентарь из раскопок в Таллине соответствует матерналам, полученным из эстонских поселений и городищ X-XII вВ. На 
основании результатов раскопок на Ратушной площади С. А. Тараканова приходит к заключению, что на месте нижнего порода не позже $\mathrm{X}$ века стало возникать эстонское ремесленное и торговое поселение. Поселение на Выштороде должно было возникнуть, по ее мненню, еще раньше. Хотя датировки С. А. Таракановой могут быть в некоторой части несколько смелымн, результаты исследования ннжнего города,- как и данные раскопок на Вышгороде, все же без всякого сомнения свидетельствуют, что Қолывань-Таллин возник как центр городского типа значительно раньше вторжения чужеземных захватчиков в начале XIII в.

По поводу различных древних названий города Таллина следует от метить, что все исследователи считают наиболее древним то наименование, которое встречается у Идриси-и, начиная с 1223 года, в древнерусских летописях, а именно Колыв ан ь, которое бытует в русском языке вплоть до XVIII века. Всеми разделяется также мнение, что название это древнеэстонского пронсхождения. Это название, как предпо лагали, происходит от имени древнего мифического богатыря Калева отсюда и «Қалеван-линна» (город Калева). Слово «калев», однако, вначале не имело значения имени собственного, оно употреблялось применительно к знати вообще.

Второе название, встречающееся в хронике Генриха Латышского, Линданисе - также относится к периоду до вторжения датских феодальных агрессоров в начале XIII века. Этим наименованием, пови димому, пользовались особенно скандинавы. В отношении пронсхождения этого слова нет единого мнения: некоторые исследователи считают, что эго слово германского пронсхождения, другне ссылаются на древнеэстонскую основу жлинд», «литна», что значило — город (влиннус»).

Встречающееся иногда в русских источниках название «Л едене п» происходит, как предполагают, от «линданисе».

Четвертое наименование - русское Ре в ель (немецкое Reval) происходит от названия древней «земли» Рявала, так как Таллин в то время являлся центром этой жземли». Нынешнее названне города Таллина происходнт от сокращенного «Таани линн» («Датский городљ).

Вышеприведенные факты свидетельствуют, что город Колывань, как тавань, узел путей сообения, центр торговли н ремесла. возник в результате развития местных условий в X-XI веках, так же, как н дру гие древнеэстонекие центры. В процессе его развития важную роль сыграло тесное общение с русскими городами, особенно с Новгородом и Псковом. В XI-XII веках этот центр был уже хорошо известен близким соседям эстонцев, о нем знали даже арабскне купцы, по данным которых Идриси и упоминает Колывань впервые в 1154 году.

Таким образом, совершенно достоверно, что Таллин возник не в результате немецко-датской агрессии, а наоборот, захватчики высадились здесь именно потому, что на этом месте уже существовал с древнейших времен населенный пункт, овладение которым сулило захватчнкам громадные выгоды, так как этот центр давал возможность покорить и отсюда эксплуатировать всю северную часть Эстонии. 